\title{
Enhancement of Transgene Expression by HDAC Inhibitors in Mouse Embryonic Stem Cells
}

\author{
Young-Eun Kim ${ }^{1,2}$, Jeong-A Park', Sang-Kyu Park ${ }^{1}$, Ho-Bum Kang', \\ Hyung-Joo Kwon ${ }^{3,4}$ and ${ }^{\dagger}$ Younghee Lee ${ }^{1,2}$ \\ ${ }^{1}$ Department of Biochemistry, College of Natural Sciences / ${ }^{2}$ Biotechnology Research Institute, \\ Chungbuk National University, Cheongju 361-763, Republic of Korea \\ ${ }^{3}$ Center for Medical Science Research $/{ }^{4}$ Department of Microbiology, College of Medicine, \\ Hallym University, Chuncheon 200-702, Republic of Korea
}

\begin{abstract}
Embryonic stem (ES) cells can self-renew and differentiate to various cells depending on the culture condition. Although ES cells are a good model for cell type specification and can be useful for application in clinics in the future, studies on ES cells have many experimental restraints including low transfection efficiency and transgene expression. Here, we observed that transgene expression after transfection was enhanced by treatment with histone deacetylse (HDAC) inhibitors such as trichostatin A, sodium butyrate, and valproic acid. Transfection was performed using conventional transfection reagents with a retroviral vector encoding GFP under the control of CMV promoter as a reporter. Treatment of ES cells with HDAC inhibitors after transfection increased population of GFP positive cells up to $180 \%$ compared with untreated control. ES cells showed normal expression of stem cell markers after treatment with HDAC inhibitors. Transgene expression was further enhanced by modifying transfection procedure. GFP positive cells selected after transfection were proved to have the stem cell properties. Our improved protocol for enhanced gene delivery and expression in mouse ES cells without hampering ES cell properties will be useful for study and application of ES cells.
\end{abstract}

Key words : Mouse embryonic stem cell, HDAC inhibitor, Transfection, Enhancement, Optimization

\section{INTRODUCTION}

ES cells are pluripotent cells derived from the inner cell mass (ICM) of embryos (Evans \& Kaufman, 1981; Thomson et al., 1998). ES cells are able to self-renew in an unlimited and symmetrical manner and have the capability of differentiation to multiple cell lineages in vitro (Brook \& Gardner, 1997; Nagy et al., 1990). Potentials of ES cells have positioned ES cells as a good model system, therefore now ES cells are widely used for studying molecular mechanisms involved in self renewal/differentiation and development, cell therapy, and drug screening (Bain et al., 1995; Lerou and Daley, 2005; Sartipy et al., 2007). To facilitate these studies, a rapid and effective gene transfer method is needed. Several techniques have been adopted to deliver genes into ES cells until now; electroporation (Mamo et al., 2010), liposome-based transfection methods (Ko et al., 2009), nucleofection (Lakshmipathy et al., 2004),

\footnotetext{
Manuscript received 23 November 2013, Received in revised form 7 December 2013, Accepted 13 December 2013

${ }^{\dagger}$ Corresponding Author : Younghee Lee, Department of Biochemistry, Chungbuk National University, 410 SungBong-ro, Heungduk-gu, Cheongju-si, Chungbuk 361-763, Republic of Korea. Tel. : +82-43-261-3387; Fax : +82-43-267-2306, E-mail : YHL4177@cbnu.ac.kr

This is an Open Access article distributed under the terms of the Creative Commons Attribution Non-Commercial License(http://creativecommons. org/licenses/by-nc/3.0) which permits unrestricted non-commercial use, distribution, and reproduction in any medium, provided the original work is properly cited.
} 
viral transfection (Gropp et al., 2003; Ma et al., 2003), and magnetofection (Lee et al., 2008). However, generally the transfection efficiency is not high. Furthermore, there is a pitfall also in expression of foreign genes in ES cells. Major constraint is that integration into the genome is poor and the exogenous gene is often silenced even when it has been successfully integrated into the genome. For example, in the case of transfection with retroviral vector, DNA methylation in the LTR leads to retrovirus silencing and defines the promoter region CpGs as a repressive element in ES cells (Swindle et al., 2004). In addition, ES cells tend to differentiate during the selection procedure and obtaining a reasonably pure cell line is very difficult (Wiles \& Johansson, 1999).

To regulate expression of a specific gene, cells have to finely control the coiling and uncoiling of DNA around histones. Acetylation and deacetylation of histones contribute to the epigenetic regulation (Grunstein, 1997). There are two classes of enzymes involved in determining the state of histone acetylation, histone acetyl transferases (HAT) and histone deacetylse (HDAC). HDAC inhibitors induced changes in the acetylation status of chromatin and other non-histone proteins, leading to changes in gene expression (Marks et al., 2000).

Trials to improve the efficiency of gene transfer and gene expression using HDAC inhibitors have been performed in various cells. It was reported that HDAC inhibitors enhance the transcription of adenoviral transgenes in cancer cells (Dion et al., 1997; Goldsmith et al., 2003; Kitazono et al., 2001). For example, a HDAC inhibitor FK228 has the capability to augment adenoviral transgene expression in several different cancer cell lines (Goldsmith et al., 2003). Adenoviral transgene products were amplified by sodium butyrate (NaB: $0.5-5 \mathrm{mM}$ ) and trichostatin A (TSA: 0.1-1 $\mu \mathrm{M}$ ) in HeLa and A549 cells (Dion et al., 1997). According to a recent study, HDAC inhibitors such as TSA, valproic acid (VPA) and OSU-HDAC42 enhance the expression of genes under the control of a CMV promoter in vitro and in vivo (Lai et al., 2010). Considering that the combined treatment of HDAC inhibitors with 5-Aza-dC (inhibitor of DNA methylase) induces synergistic activation of a transgene, it is likely that there is a cross-talk between histone acetylation and DNA methylation (Choi et al., 2005).

Here, we tested the effect of HDAC inhibitors on transfection in mouse ES cells and found that HDAC inhibitors enhance the transgene expression. In addition, we further enhanced gene delivery and transgene expression by modifying transfection condition.

\section{MATERIALS AND METHODS}

\section{Maintenance of mouse ES cells}

R1 mouse ES cells were maintained on irradiated mouse embryonic fibroblast (MEF) cells in ES medium which contains DMEM (Hyclone, Logan, UT), 15\% fetal bovine serum (Hyclone), 2 mM L-glutamine, $0.1 \mathrm{mM} \beta$-mercaptoethanol (Sigma-Aldrich, St. Louis, MO), and 1\% nonessential amino acids (Gibco, Carlasbad, CA). Mouse ES cells were detached from the plates by incubation in TrypLE (Gibco) solution for $3 \mathrm{~min}$ at $37^{\circ} \mathrm{C}$ in a $5 \% \mathrm{CO}_{2}$ atmosphere and then harvested via centrifugation. Mouse ES cells were washed with medium and then moved into the MEF plated dish and maintained at $37^{\circ} \mathrm{C}$ in a $5 \% \mathrm{CO}_{2}$ incubator.

\section{Transfection of ES cells followed by treatment} with HDAC inhibitors

R1 cells were cultured on $0.1 \%$ gelatin-coated plates in ES medium supplemented with leukemia inhibitory factor (LIF, $10 \mathrm{ng} / \mathrm{ml}$ ). R1 cells were harvested using TrypLE solution and then $4 \times 10^{5}$ cells were seeded into $0.1 \%$ gelatin-coated 12 well plates $6 \mathrm{hr}, 9 \mathrm{hr}, 12 \mathrm{hr}$, and $16 \mathrm{hr}$ prior to transfection. The pMSCV-neo-CMV-GFP (pMSCV-GFP) construct was generated in this study using pMSCV-neo as a parental vector (Grez et al., 1990; Miller and Rosman, 1989). The pMSCV-GFP vector was isolated using Qiagen plasmid MIDI-prep kit (Qiagen, West Sussex, UK).

For transfection using the Lipofectamine ${ }^{\mathrm{TM}} 2000$ (Invitrogen, Carlsbad, CA), $1.6 \mu \mathrm{g}$ of plasmid DNA (pMSCV-GFP) 
and $4 \mu \mathrm{l}$ of Lipofectamine ${ }^{\mathrm{TM}} 2000$ reagent were mixed with $100 \mu \mathrm{l}$ each of opti-MEM for $5 \mathrm{~min}$ at room temperature. Two solutions were then mixed and incubated for 20 min. This complex was added into antibiotics-free ES medium in each well of 12 well plates. For transfection using the FuGENE ${ }^{\circledR} \mathrm{HD}$ (Roche, Indianapolis, IN, USA) reagent, $1.0 \mu \mathrm{g}$ DNA and $3 \mu \mathrm{l}$ of FuGENE ${ }^{\circledR} \mathrm{HD}$ were applied to each well of 12 well plates and the plates were incubated for $15 \mathrm{~min}$ at room temperature. After transfection with Lipofectamine ${ }^{\mathrm{TM}} 2000$ or FuGEN ${ }^{\circledR}$ E

HD, HDAC inhibitors were added at the indicated concentration and the plates were incubated for 1 day at 37 in a $\mathrm{CO}_{2}$ incubator before analysis for the GFP or stem cell marker expression. HDAC inhibitors (Sigma-Aldrich) used in this study are as followings: trichostatin A (TSA), sodium butyrate (NaB), and valproic acid (VPA).

\section{Flow cytometry}

The expression of GFP was assessed by measuring fluorescence using FACScan. For staining of stem cell markers, control and trasnfected ES cells were fixed and permeabilized by cytofix/cytoperm ${ }^{\mathrm{TM}}$ (BD Biosciences, Bedford, MA). The cytofix/cytoperm ${ }^{\mathrm{TM}}$ wash solution was added to the cells together with individual primary antibodies to Oct-3/4 (BD Biosciences), Sox-2, Klf-4, and Nanog (Santa Cruz Biotechnology, Inc., Santa Cruz, CA) and incubated for $1 \mathrm{hr}$. After washing with cytofix/cytoperm ${ }^{\mathrm{TM}}$ wash solution, the cells were incubated with the FITCconjugated or Alexa 594-labeled secondary antibody (Invitrogen, Carlsbad, CA, USA) in cytofix/cytoperm ${ }^{\mathrm{TM}}$ wash solution at 4 in the dark for $1 \mathrm{hr}$. After washing, samples were analyzed with FACScan.

\section{RT-PCR}

Total RNA was isolated using TRI reagent ${ }^{\circledR}$, according to the manufacturer's protocol (MRC, Cincinnati, $\mathrm{OH}$, USA). The final pellet was dissolved in $20 \mu \mathrm{l}$ of diethylpyrocarbonate (DEPC)-treated distilled water. $5 \mathrm{\mu g}$ of total RNA was reverse-transcribed in the first-strand buffer containing $6 \mu \mathrm{g} / \mathrm{ml}$ oligo (dT) primer, $50 \mathrm{U}$ M-MLV reverse transcriptase (Invitrogen), 2 mM dNTP, and 40 U RNaseOUT ${ }^{\mathrm{TM}}$ recombinant ribonuclease inhibitor (Invitrogen). The reaction was conducted at $42^{\circ} \mathrm{C}$ for $1 \mathrm{hr}$. One microliter of the cDNA synthesis was subjected to the standard PCR reaction for 20-30 cycles of denaturation for $60 \mathrm{sec}$ at $95^{\circ} \mathrm{C}$, annealing for $60 \mathrm{sec}$ at $58 \mathrm{C}$, and elongation for $60 \mathrm{sec}$ at $72^{\circ} \mathrm{C}$. The primer sequences were: GAPDH, 5'-ACCA CAGTCCATGCCATCAC-3' (sense) and 5'-TCCACCA CCCTGTTGCTGTA-3’ (anti-sense) (452 bp); Oct4, 5’CTCGAACCACATCCTTCTCT-3' (sense) and 5'- GGC

GTTCTCTTTGGAAAGGTGTTG-3' (antisense) (313 bp); Nanog, 5'- AGG GTC TGC TAC TGA GAT GCT CTG -3' (sense) and 5'- CAA CCA CTG GTT TTT CTG CCA CCG -3' (antisense).

\section{Selection and characterization of transfected cells}

The transfected cells were cultured in the presence of $250 \mathrm{\mu g} / \mathrm{ml}$ G418 (Sigma-Aldrich) and G418 resistant cells were selected for 2-3 weeks. Cells were maintained on $0.1 \%$ gelatin-coated dish in ES culture medium supplemented with LIF. After culture for 3 weeks, GFP expression was determined by measuring fluorescence using FACScan (BD Biosciences). Expression of stem cell markers such as Oct-3/4, Sox-2, and Klf-4 was assessed by flow cytometry using FACScan.

\section{Statistical analysis}

Results are expressed as mean \pm standard deviation. Statistical significance between two samples was evaluated using the Student's $t$ test. A $p$-value of $<0.05$ was taken as statistically significant.

\section{RESULTS AND DISCUSSION}

\section{Enhancement of transgene expression by HDAC} inhibitors in R1 mouse ES cells

Several previous reports suggest that the efficiency of gene transfer and gene expression can be enhanced by HDAC inhibitors. Therefore, we investigated the effect of HDAC inhibitors on transfection efficiency in R1 mouse 
ES cells.

Many cellular and viral promoters, including cellular polypeptide chain elongation factor-1 (EF1), cytomegalovirus (CMV), and the Rous sarcoma virus (RSV) promoters, have been used to drive gene expression in ES cells (Ward and Stern, 2002; Zeng et al., 2003). Individual promoters have different capabilities to direct expression of reporter gene expression in ES cells and the CMV and EF1 promoters are known to be most effective (Zeng et al., 2003). Here, we constructed an expression vector, pMSCV-GFP, harboring enhanced GFP gene in the downstream of CMV promoter.

HDAC inhibitors such as NaB, VPA, and TSA were treated for $24 \mathrm{hr}$ after transfection using two different transfection reagents, Lipofectamine ${ }^{\mathrm{IM}} 2000$ and FuGENE ${ }^{\circledR}$ $\mathrm{HD}$, and the GFP expression levels were examined by FACS analysis. Population of GFP positive cells increased up to about $180 \%$ in the presence of the HDAC inhibitors compared to untreated control (Fig. 1). We obtained similar results when we used either Lipofectamine ${ }^{\mathrm{TM}} 2000$ (Fig. 1A) or FuGENE ${ }^{\circledR}$ HD (Fig. 1B). However, there was some difference in the efficacy of the transfection.

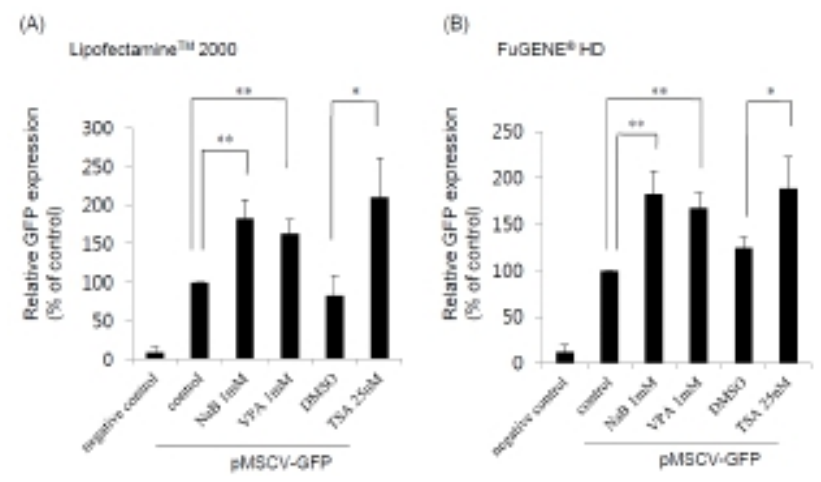

Fig. 1. Increase of transgene expression by HDAC inhibitors in mouse ES cells. Population of GFP positive cells was assessed by FACS analysis at $24 \mathrm{hr}$ after transfection with Lipofectamine $^{\mathrm{TM}} 2000$ (A) and FuGENE ${ }^{\circledR}$ HD (B). Transfected ES cells were treated with HDAC inhibitors at the indicated concentration for the incubation period. Relative percentage of GFP positive cells compared to the control is shown graphically taking the control as $100 \%$. The experiments were performed at least three times. $* P<0.05, * * P<0.01$ by paired student $t$-test.
When we checked the percentage of GFP positive cells in the case of Lipofectamine ${ }^{\mathrm{TM}} 2000$, the transfection efficiency in the presence of HDAC inhibitor was observed about $15 \%$. In contrast, a lower percentage of GFP positive cells were obtained by FuGENE ${ }^{\circledR}$ HD treatment ( 4\%). These data reveal that HDAC inhibitors may be generally used as an enhancer for efficient gene delivery and expression in mouse ES cell. Additionally, we tested another vector including CMV promoter, pEGFP-C2 (Clontech) and found that the transgene expression was also enhanced by HDAC inhibitors (data not shown). This result suggests that enhancement of transgene expression in ES cells can be a general effect of HDAC inhibitors irrespective of the vector types.

According to recent reports in mouse ES cells, DNA methyltransferase and HDAC inhibitors, especially VPA, improve the efficiency of reprogramming mouse embryonic fibroblasts (MEF) using genetic factors (Huangfu et al., 2008a; Huangfu et al., 2008b). TSA treatment after somatic nuclear transfer in mice dramatically improved the efficacy of current cloning technique (Kishigami et al., 2006). VPA overrode Polycomb-mediated silencing of Hoxb gene in mouse ES cells (Boudadi et al., 2013). Also, HDAC inhibitor and DNA methyl transferases alter imprinted gene regulation in ES cells. Histone modification plays an important role in establishing a chromatin state permissive to early embryonic gene expression in ES cells (Baqir and Smith, 2006). In this context, our results showing effect of HDAC inhibitors on transgene expression suggest that HDAC mediated chromatin remodeling may contribute to a low ectopic gene expression in ES cells. As we examined GFP expression after transfection, the outcome can be affected by gene delivery efficiency as well as the extent of the delivered trangene expression. Therefore, it is also possible that modulation of microtubule acetylation through HDAC6 inhibitor leads to increase of gene delivery efficiency as previously reported in human adenocarcinoma A549 cells (Vaughan et al., 2008). For better understanding on this issue, further detailed investigation is required in the future. 


\section{Optimization of condition for effective transfection}

Although the transgene expression was increased by the HDAC inhibitors (Fig. 1), the percentage of transfected GFP positive cells is still low. Therefore, to get a better efficiency, we tried optimization of the protocol. As ES cells are inclined to form clumps, exposed surface region of ES cells is limited. We usually transfer ES cells onto a culture plate and culture for $16 \mathrm{hr}$ prior to transfection. Therefore, we tried to adjust the plating time of ES cells: three different plating time periods $(6 \mathrm{hr}, 9 \mathrm{hr}$, and 12 hr). HDAC inhibitors were treated at the indicated concentration after transfection by Lipofectamine ${ }^{\mathrm{TM}} 2000$ and FuGENE ${ }^{\circledR}$ HD. As shown in Fig. 2, population of GFP positive cells after transfection using Lipofectamine ${ }^{\mathrm{TM}}$ 2000 in mouse ES cells increased by HDAC inhibitors in a dose-dependent manner. Lipofectamine ${ }^{\mathrm{TM}} 2000$ (Fig. 2) and FuGENE ${ }^{\circledR}$ HD (data not shown) produced similar pattern of transfection efficiency even though overall transfection efficiency was higher with Lipofectamine ${ }^{\text {TM }}$ 2000. The highest transfection efficiency was appeared when we performed transfection after plating the cells for $6 \mathrm{hr}$ and incubate the cells in the presence of HDAC inhibitors for $24 \mathrm{hr}$. Thus, this condition was defined as a standard condition for the following experiments. As both of the GFP positive cell population and the mean fluorescence index (MFI) increased simultaneously, it is likely that the modified protocol enhances gene delivery as well as the transgene expression.

\section{Transfected mouse ES cells maintain stem cell} marker expression

Previous studies have shown that HDAC inhibitors, including TSA, induced the early differentiation and altered characterization of ES cell (Karantzali et al., 2008; Park et al., 2011). It was also reported that mSin3A-HDAC complex is involved in the maintenance of ES cell pluripotency (Baltus et al., 2009). Therefore, to evaluate whether these HDAC inhibitors change the stem cell properties during the transfection procedure in this study, we treated $\mathrm{NaB} 1 \mathrm{mM}$, VPA $1 \mathrm{mM}$, and TSA $25 \mathrm{nM}$ for $24 \mathrm{hr}$ after transfection with Lipofectamine ${ }^{\mathrm{TM}} 2000$ and examined expression of the stem cell markers.

We first confirmed similar expression of stem cell markers Oct4 and Nanog mRNAs in the transfected ES cells (Fig. 3A). Next, we analyzed the expression of stem cell markers such as Oct4, Nanog, Sox-2, and KLF4 after transfection procedure at the protein level. Expression of stem cell markers in the transfected cells was similar with that in the untreated control mouse ES cells as determined by FACS analysis (Fig. 3B). These results
(A)

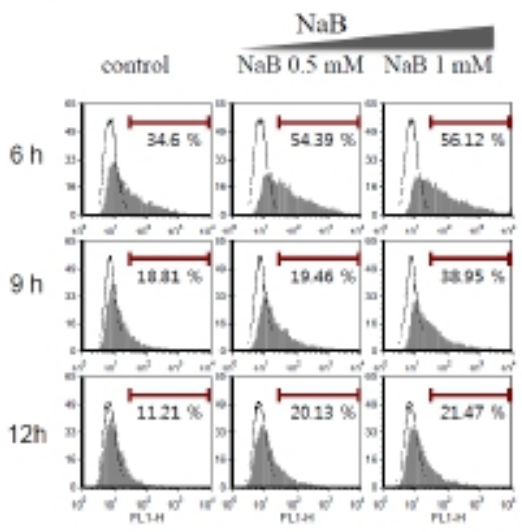

(B)

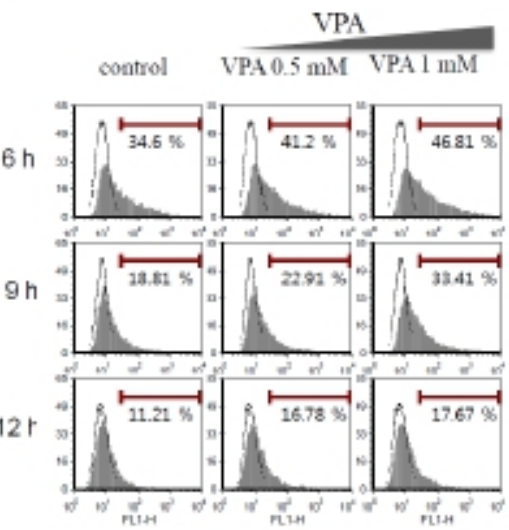

(C)

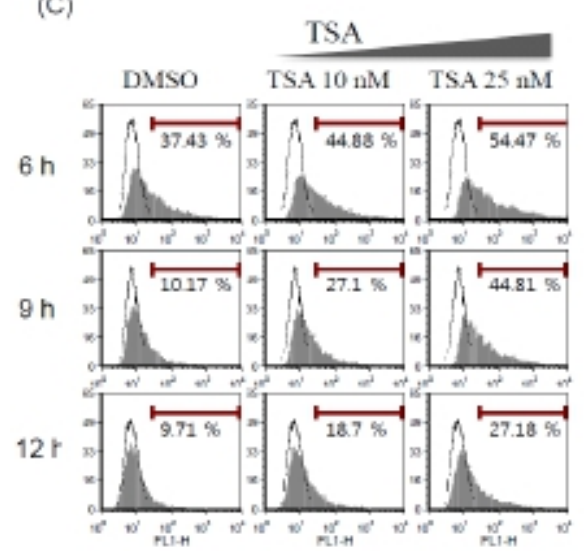

Fig. 2. Optimization of condition for effective transfection using HADC inhibitors. Population of GFP positive cells was determined by FACS analysis at $24 \mathrm{hr}$ after transfection with Lipofectamine ${ }^{\mathrm{TM}}$ 2000. Transfected ES cells were treated with HDAC inhibitors such as NaB (A), VPA (B) and TSA (C) at the indicated concentration for the incubation period. The percentage of GFP positive cells was monitored varying the plating time of mouse ES cells before transfection (6 hr, $9 \mathrm{hr}$, and $12 \mathrm{hr}$ ). 


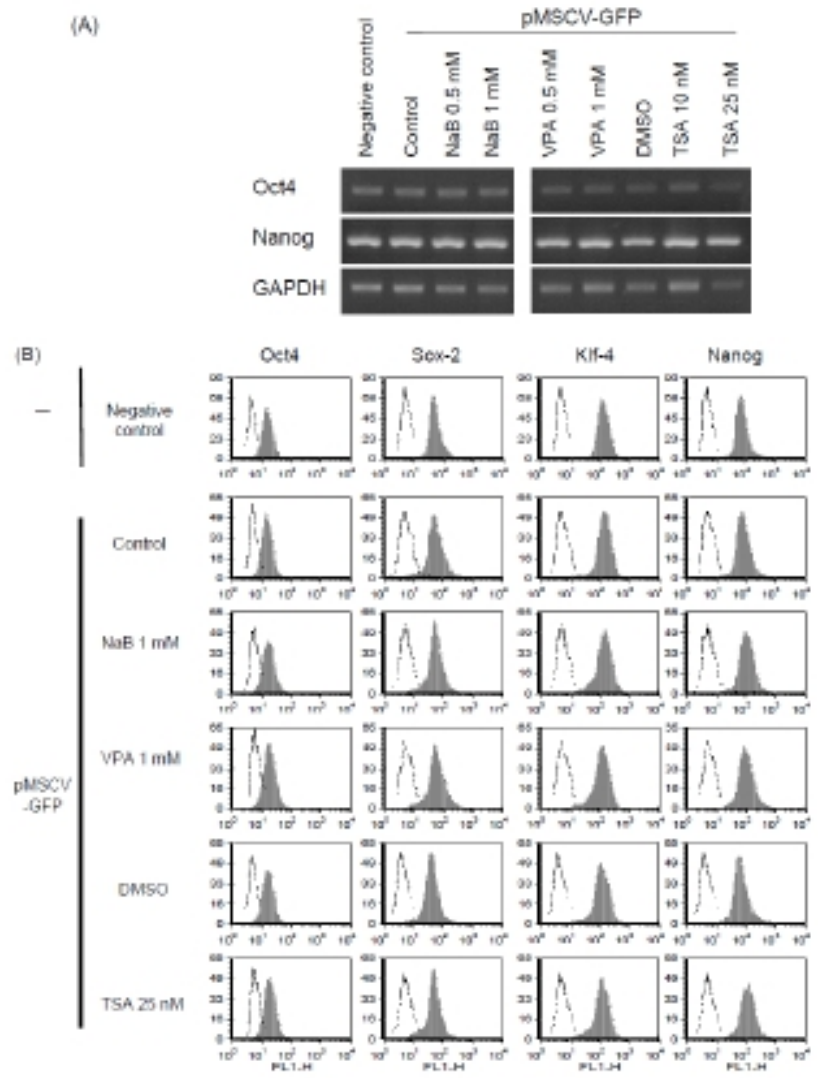

Fig. 3. Characterization of transfected mouse ES cells. GPF positive mouse ES cells were characterized after transfection according to the optimized protocol. (A) Expression of stem cell markers was determined by RT-PCR. Expression of Oct4 and Nanog mRNA was analyzed. (B) Expression of stem cells markers such as Oct4, Sox-2, Klf-4, and Nanog was determined by FACS analysis after immunostaining with respective antibodies.

suggest that transfection with Lipofectamine ${ }^{\mathrm{TM}} 2000$ and treatment with HDAC inhibitors at the concentration we used permits maintenance of an undifferentiated state of ES cells, at least in the context of stem cell marker expression. It is consistent with previous study reporting that low concentration of $\mathrm{NaB}(0.1 \mathrm{mM})$ can be used instead of bFGF: the culture medium including $\mathrm{NaB}$ could maintain human ES cells in a feeder free culture condition (Kim et al., 2012; Ware et al., 2009). The human ES cells cultured in the modified condition had normal molecular marker expression compared with control cells. Also, other HDAC inhibitors, such as TSA (10 $\mathrm{nM})$ and VPA $(0.5 \mathrm{mM})$ were shown to support expression of stem cell markers (Kim et al., 2012; Ware et al., 2009). Therefore, it is likely that optimal concentration of HDAC inhibitor doesn't affect or even enhance the stem cell properties of ES cells.

\section{Selected transgenic GFP positive cells maintain} stem cell marker expression

To obtain the stable transgenic ES cells, we next tried to select G418-resistant cells and to verify GFP and stem cell marker expression. Mouse ES cells were transfected with our modified protocol in the presence of $\mathrm{NaB}$. After $24 \mathrm{hr}$, we changed medium and added $250 \mu \mathrm{g} / \mathrm{ml}$ of G418. G418-resistant cells were selected for 2-3 weeks and expression of GFP was analyzed by FACS (Fig. 4A). These cells were well maintained in vitro and showed typical ES cell characteristics. More than $90 \%$ of total cells were positive for the Oct4, Sox-2, and Klf4 markers in FACS analysis, which is comparable to the

(A)
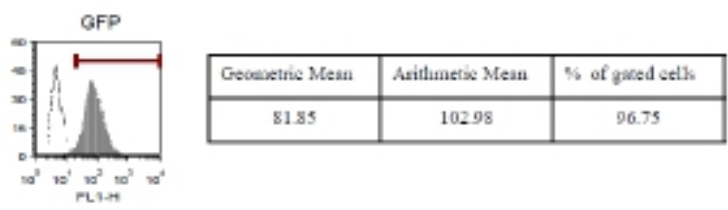

(8)
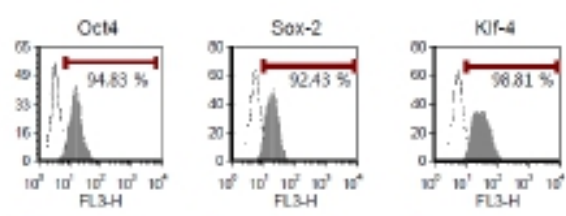

(G418 solocted R1)
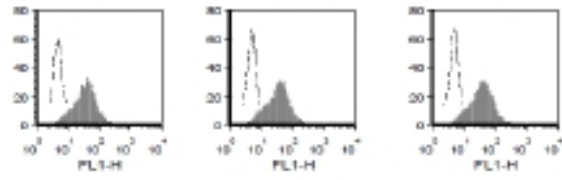

Stem col marker
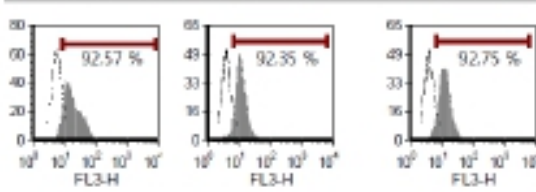

\{R1)

stam col marker

Fig. 4. Selection of G418 resistant cells and characterization of the transgenic ES cells. (A) Mouse ES cells were selected with G418 after transfection with pMSCV-GFP using Lipofectamine $^{\mathrm{TM}} 2000$ and NaB; high percentage of cells expressed GFP. (B) Stem cell marker expression in GFP positive mouse ES cells was determined by FACS analysis. 
expression pattern of parental R1 ES cells (Fig. 4B). We also confirmed typical ES cell morphology and positive staining of alkaline phosphatase (data not shown). Therefore, we suggest that the transfection and treatment with HDAC inhibitor do not interrupt stem cell properties of ES cells and the transgenic ES cells maintain their authentic properties.

Taken together, our results suggest that treatment with HDAC inhibitors and modification of plating time can improve the efficiency of transgene delivery and expression in mouse ES cells. Our method will be useful for study and application of ES cells by facilitating genetic modification in mouse ES cells.

\section{ACKNOWLEDGMENTS}

This work was supported by a grant (SC-2260) from Stem Cell Research Center of the $21^{\text {st }}$ Century Frontier Research Program and a grant (2011-0011742) from the Korea Research Foundation.

\section{REFERENCES}

Bain G, Kitchens D, Yao M, Huettner JE, Gottlieb DI (1995) Embryonic stem cells express neuronal properties in vitro. Dev Biol 168:342-357.

Baltus GA, Kowalski MP, Tutter AV, Kadam S (2009)

A positive regulatory role for the mSin3A-HDAC complex in pluripotency through Nanog and Sox2. J Biol Chem 284:6998-7006.

Baqir S, Smith LC (2006) Inhibitors of histone deacetylases and DNA methyltransferases alter imprinted gene regulation in embryonic stem cells. Cloning Stem Cells 8:200-213.

Boudadi E, Stower H, Halsall JA, Rutledge CE, Leeb M, Wutz A, O'Neill LP, Nightingale KP, Turner BM (2013) The histone deacetylase inhibitor sodium valproate causes limited transcriptional change in mouse embryonic stem cells but selectively overrides Polycombmediated Hoxb silencing. Epigenetics Chromatin 6:11.
Brook FA, Gardner RL (1997) The origin and efficient derivation of embryonic stem cells in the mouse. Proc Natl Acad Sci U S A 94:5709-5712.

Choi KH, Basma H, Singh J, Cheng PW (2005) Activation of CMV promoter-controlled glycosyltransferase and beta-galactosidase glycogenes by butyrate, tricostatin A, and 5-aza-2'-deoxycytidine. Glycoconj J 22:63-69. Dion LD, Goldsmith KT, Tang DC, Engler JA, Yoshida M, Garver RI Jr (1997) Amplification of recombinant adenoviral transgene products occurs by inhibition of histone deacetylase. Virology 231:201-209.

Evans MJ, Kaufman MH (1981) Establishment in culture of pluripotential cells from mouse embryos. Nature 292:154-156.

Goldsmith ME, Kitazono M, Fok P, Aikou T, Bates S, Fojo T (2003) The histone deacetylase inhibitor FK228 preferentially enhances adenovirus transgene expression in malignant cells. Clin Cancer Res 9:5394-5401.

Grez M, Akgun E, Hilberg F, Ostertag W (1990) Embryonic stem cell virus, a recombinant murine retrovirus with expression in embryonic stem cells. Proc Natl Acad Sci U S A 87:9202-9206.

Gropp M, Itsykson P, Singer O, Ben-Hur T, Reinhartz E, Galun E, Reubinoff BE (2003) Stable genetic modification of human embryonic stem cells by lentiviral vectors. Mol Ther 7:281-287.

Grunstein M (1997) Histone acetylation in chromatin structure and transcription. Nature 389:349-352.

Huangfu D, Maehr R, Guo W, Eijkelenboom A, Snitow $\mathrm{M}$, Chen AE, Melton DA (2008a) Induction of pluripotent stem cells by defined factors is greatly improved by small-molecule compounds. Nat Biotechnol 26: 795-797.

Huangfu D, Osafune K, Maehr R, Guo W, Eijkelenboom A, Chen S, Muhlestein W, Melton DA (2008b) Induction of pluripotent stem cells from primary human fibroblasts with only Oct4 and Sox2. Nat Biotechnol 26:1269-1275.

Karantzali E, Schulz H, Hummel O, Hubner N, Hatzopoulos A, Kretsovali A (2008) Histone deacetylase inhibition 
accelerates the early events of stem cell differentiation: transcriptomic and epigenetic analysis. Genome Biol 9:R65.

Kim HT, Lee KL, Hwang DY (2012) The feeder-free culture of human embryonic stem cells and induced pluripotent stem cells in the presence of histone deacetylase inhibitors. Tissue Eng Regen Med 9:5564.

Kishigami S, Mizutani E, Ohta H, Hikichi T, Thuan NV, Wakayama S, Bui HT, Wakayama T (2006) Significant improvement of mouse cloning technique by treatment with trichostatin A after somatic nuclear transfer. Biochem Biophys Res Commun 340:183-189.

Kitazono M, Goldsmith ME, Aikou T, Bates S, Fojo T (2001) Enhanced adenovirus transgene expression in malignant cells treated with the histone deacetylase inhibitor FR901228. Cancer Res 61:6328-6330.

Ko BS, Chang TC, Shyue SK, Chen YC, Liou JY (2009) An efficient transfection method for mouse embryonic stem cells. Gene Ther 16:154-158.

Lai MD, Chen CS, Yang CR, Yuan SY, Tsai JJ, Tu CF, Wang CC, Yen MC, Lin CC (2010) An HDAC inhibitor enhances the antitumor activity of a CMV promoter-driven DNA vaccine. Cancer Gene Ther 17:203-211.

Lakshmipathy U, Pelacho B, Sudo K, Linehan JL, Coucouvanis E, Kaufman DS, Verfaillie CM (2004) Efficient transfection of embryonic and adult stem cells. Stem Cells 22:531-543.

Lee CH, Kim EY, Jeon K, Tae JC, Lee KS, Kim YO, Jeong MY, Yun CW, Jeong DK, Cho SK, Kim JH, Lee HY, Riu KZ, Cho SG, Park SP (2008) Simple, efficient, and reproducible gene transfection of mouse embryonic stem cells by magnetofection. Stem Cells Dev 17:133-141.

Lerou PH, Daley GQ (2005) Therapeutic potential of embryonic stem cells. Blood Rev 19:321-331.

Ma Y, Ramezani A, Lewis R, Hawley RG, Thomson JA (2003) High-level sustained transgene expression in human embryonic stem cells using lentiviral vectors.
Stem Cells 21:111-117.

Mamo S, Kobolak J, Borbiro I, Biro T, Bock I, Dinnyes A (2010) Gene targeting and calcium handling efficiencies in mouse embryonic stem cell lines. World J Stem Cells 2:127-140.

Marks PA, Richon VM, Rifkind RA (2000) Histone deacetylase inhibitors: inducers of differentiation or apoptosis of transformed cells. J Natl Cancer Inst 92:1210-1216.

Miller AD, Rosman GJ (1989) Improved retroviral vectors for gene transfer and expression. BioTechniques 7: 980-982, 984-986, 989-990.

Nagy A, Gocza E, Diaz EM, Prideaux VR, Ivanyi E, Markkula M, Rossant J (1990) Embryonic stem cells alone are able to support fetal development in the mouse. Development 110:815-821.

Park JA, Kim YE, Seok HJ, Park WY, Kwon HJ, Lee Y (2011) Differentiation and upregulation of heat shock protein 70 induced by a subset of histone deacetylase inhibitors in mouse and human embryonic stem cells. BMB Reports 44:176-181.

Sartipy P, Bjorquist P, Strehl R, Hyllner J (2007) The application of human embryonic stem cell technologies to drug discovery. Drug Discov Today 12:688-699.

Swindle CS, Kim HG, Klug CA (2004) Mutation of CpGs in the murine stem cell virus retroviral vector long terminal repeat represses silencing in embryonic stem cells. J Biol Chem 279:34-41.

Thomson JA, Itskovitz-Eldor J, Shapiro SS, Waknitz MA, Swiergiel JJ, Marshall VS, Jones JM (1998) Embryonic stem cell lines derived from human blastocysts. Science 282:1145-1147.

Vaughan EE, Geiger RC, Miller AM, Loh-Marley PL, Suzuki T, Miyata N, Dean DA (2008) Microtubule acetylation through HDAC6 inhibition results in increased transfection efficiency. Mol Ther 16:18411847.

Ward CM, Stern PL (2002) The human cytomegalovirus immediate-early promoter is transcriptionally active in undifferentiated mouse embryonic stem cells. Stem 
Cells 20:472-475.

Ware CB, Wang L, Mecham BH, Shen L, Nelson AM, Bar M, Lamba DA, Dauphin DS, Buckingham B, Askari B, Lim R, Tewari M, Gartler SM, Issa JP, Pavlidis P, Duan Z, Blau CA (2009) Histone deacetylase inhibition elicits an evolutionarily conserved self-renewal program in embryonic stem cells. Cell Stem Cell 4:359-369.
Wiles MV, Johansson BM (1999) Embryonic stem cell development in a chemically defined medium. Exp Cell Res 247:241-248.

Zeng X, Chen J, Sanchez JF, Coggiano M, Dillon-Carter O, Petersen J, Freed WJ (2003) Stable expression of hrGFP by mouse embryonic stem cells: promoter activity in the undifferentiated state and during dopaminergic neural differentiation. Stem Cells 21:647-653. 